\title{
Bone Scintigraphy and SPECT/CT of Bisphosphonate-Induced Osteonecrosis of the Jaw
}

Franca Dore ${ }^{1}$, Luca Filippi ${ }^{1}$, Matteo Biasotto ${ }^{2}$, Silvia Chiandussi ${ }^{2}$, Fabio Cavalli ${ }^{3}$, and Roberto Di Lenarda ${ }^{2}$

${ }^{1}$ Section of Nuclear Medicine Hospital Maggiore-Trieste, Trieste, Italy; ${ }^{2}$ Section of Dental Sciences, University of Trieste, Trieste, Italy; and ${ }^{3}$ Section of Radiodiagnostic Imaging, Hospital Maggiore-Trieste, Trieste, Italy

Endovenous bisphosphonate therapy seems associated with osteonecrosis of the jaw. The aim of this study was to evaluate the additional diagnostic value of hybrid SPECT/CT in 99mTc-methylene diphosphonate 3-phase bone scintigraphy of osteonecrosis of the jaw in bisphosphonate-treated patients. Methods: We studied 15 patients (12 women and 3 men) with extraoral tumors affected by lytic bone metastases and multiple myeloma. All patients were previously treated with intravenous bisphosphonates (zoledronic acid) for 1-3 y, were negative for dental disease at clinical examination, and had suspected osteonecrosis of the jaw. All 15 patients underwent panoramic x-ray orthopantomography, CT or MRI (or both), microbiologic examination, 3-phase bone scintigraphy, and SPECT/CT of the maxillary region. Results: Three-phase bonescintigraphy showed increased perfusion and an increased blood pool in 9 of 12 and 10 of 12 patients, respectively; at the metabolic phase, SPECT was positive in all patients and showed abnormal hyperactivity in the maxilla of 2 patients, in the mandible of 9 patients, and in both the mandible and the maxilla of 4 patients. Hybrid SPECT/CT was of particular value in 8 of 15 patients, allowing discrimination of the osteonecrotic core from nearby hyperactivity due to viable bone. Whole-body scintigraphy showed remote and multiple metastases in all patients. Orthopantomography showed nonspecific bone rarefaction in all patients but was not able to aid diagnosis of osteonecrosis of the jaw. CT and MRI showed anomalies in all symptomatic patients: CT was helpful in evaluating both cortical and trabecular bone aspects, and MRI was able to detect soft-tissue involvement but not cortical bone destruction. Conclusion: In appropriately selected oncology patients treated with bisphosphonates, an increased uptake of ${ }^{99 m} \mathrm{Tc}-$ methylene diphosphonate in maxillary bones may suggest probable osteonecrosis of the jaw. In such cases, SPECT/CT may be of value in increasing the diagnostic accuracy of bone scanning, providing a precise functional anatomic correlation for the definition of the extent of disease.

Key Words: bone scintigraphy; SPECT/CT; jaw; osteonecrosis

J Nucl Med 2009; 50:30-35

DOI: 10.2967/jnumed.107.048785

Received Nov. 2, 2007; revision accepted May 16, 2008.

For correspondence or reprints contact: Franca Dore, S.C. Medicina Nucleare, Azienda Ospedaliero-Universitaria Trieste, Via della Pietà no.

19, 34100 Trieste, Italy.

E-mail: franca.dore@aots.sanita.fvg.it

COPYRIGHT $\odot 2009$ by the Society of Nuclear Medicine, Inc. n the literature, an increasing number of cases of osteonecrosis of the jaw after intravenous administration of the new generation of bisphosphonates (pamidronate and zoledronic acid) has been reported $(1,2)$. Commonly used to treat patients with neoplasia, especially in the case of lytic bone metastases (generated from breast and prostate cancer) and multiple myeloma, bisphosphonates reduce such skeletal complication as pain, pathologic fractures, limited mobility, malignant hypercalcemia, and spinal cord compression $(3,4)$. In Italy, a growing number of cases have been reported, and the U.S. Food and Drug Administration has also been paying attention to osteonecrosis as a possible complication of intravenous bisphosphonate use (4). A careful clinical assessment is also necessary using diagnostic imaging to better estimate the extent of skeletal lesions. Digital orthopanoramic radiography, CT, MRI, and ${ }^{99 \mathrm{~m} T c}$ bone scintigraphy represent useful diagnostic tools revealing different structural and functional aspects of bone involvement. Standard diagnostic criteria and study through imaging are still missing, and this lack obviously weighs on therapeutic decisions (5).

Bone scanning with the more recently introduced types of instrumentation allows adequate visualization of metabolic changes in the entire skeleton. However, bone scans are characterized by elevated sensitivity and low specificity. SPECT can improve the diagnostic accuracy of bone functional imaging and is more sensitive than planar imaging (6). New hybrid SPECT/CT systems combining SPECT with low-dose single-slice CT have proven useful for better characterization of skeletal lesions. Moreover, hybrid devices that allow the functional significance of CT lesions to be defined also improve the specificity of SPECT by excluding disease at sites of physiologic uptake (7).

The aim of this study was to evaluate the additional value of SPECT/CT in ${ }^{99 \mathrm{~m}} \mathrm{Tc}$-methylene diphosphonate 3 -phase bone scanning of a group of 15 bisphosphonatetreated patients with clinically suspected osteonecrosis of the jaw. 


\section{MATERIALS AND METHODS}

Patients

We investigated 15 patients with clinically suspected osteonecrosis of the jaw (12 women and 3 men; average age, $70 \pm 8.4$ y; range, 54-86 y). All patients had undergone functional imaging during restaging because they were affected by extraoral tumors: 9 had breast cancer, 2 lung cancer, and 4 multiple myeloma.

All patients underwent a dental assessment before our diagnostic evaluation and met the requirements adopted by the American Association of Oral and Maxillofacial Surgeons. All patients had previously been treated intravenously with zoledronic acid (zoledronate) (4 mg per 15-min infusion every $3 \mathrm{wk}$ ) for $2.2 \pm$ 0.6 y (range, $1-3$ y). Mandibular and maxillary pain occurred in 2 patients approximately 9 mo after the beginning of the bisphosphonate therapy; in all other patients, pain began after about $2 \mathrm{y}$.

At clinical examination, 8 patients had necrosis associated with severe pain, edema, and exposed bone; 5 patients had pain with signs of acute infection such as swelling, fever, and in 1 case a purulent fistula; and 2 patients did not have pain but only swelling and fever. Among these 8 patients, 6 presented with visibly exposed bone during clinical follow-up, about 3-6 mo after our clinical examination; 1 died without presenting exposed bone, but mandibular osteonecrosis of the jaw was confirmed at autopsy.

A dental history revealed a correlation between osteonecrosis of the jaw and dental extraction $(n=5)$, periimplantitis $(n=1)$, bone biopsy $(n=1)$, preprosthetic surgery $(n=1)$, and a traumatic lesion $(n=1)$. These probable predisposing factors occurred from 1 to 8 mo before the development of osteonecrosis in the jaws. In 6 patients, we could not identify any precise associated factor. None of the 15 patients had undergone radiotherapy in the regions of maxillary or mandibular osteonecrosis.

In all patients, swabs and bone cultures were performed to check for the presence of secondary infection. Moreover, 8 patients underwent biopsy of the bony exposure to exclude metastatic bone involvement.

\section{Radiologic Examinations}

In all patients, radiologic examinations included orthopantomography and CT or MRI (or both); CT was performed using an Aquilon 16 scanner (Toshiba) at $120 \mathrm{kV}$ and $200 \mathrm{~mA}$, with a slice thickness of $0.5 \mathrm{~mm}$; MR images were obtained using a $1.5-\mathrm{T}$ superconductive magnet (Gyroscan Intera; Philips) before and after intravenous administration of a gadolinium-containing contrast agent.

\section{Nuclear Medicine Imaging}

In 12 of 15 patients, 3-phase bone scintigraphy was immediately performed after the intravenous injection of a $740-\mathrm{MBq}$ bolus of ${ }^{99 \mathrm{~m}} \mathrm{Tc}$-methylene diphosphonate (Osteosol; GE Healthcare). Data were obtained in a $64 \times 64$ matrix in the anterior view every $1 \mathrm{~s}$ for the first minute. The blood-pool image was obtained at $4 \mathrm{~min}$ after injection for $1 \mathrm{~min}$. The perfusion index was obtained by radionuclide angiography. We set symmetric regions of interest on the maxillary or mandibular segment and on a contralateral normal area to calculate the perfusion index. The time-activity curve of each region of interest was generated, and the perfusion index was determined by dividing the peak count of the arterial phase in the jaw with suspected osteonecrosis by the peak count in the contralateral normal area. For analysis of the bloodpool image, we manually set the region of interest on the jaw and set a symmetric region of interest on the contralateral normal area as a control. Subsequently, we obtained a time-activity curve relative to each region of interest.

Whole-body scintigraphy was performed with continuous scanning of both the anterior and the posterior projections with a speed of $18 \mathrm{~cm} / \mathrm{min}, 3 \mathrm{~h}$ after intravenous injection of ${ }^{99 \mathrm{~m}} \mathrm{Tc}-$ methylene diphosphonate, using a double-head $\gamma$-camera (Infinia Hawkeye [GE Healthcare] or e.cam [Siemens]) equipped with low-energy, high-resolution collimators: a $10 \%$ energy window was centered over the $140-\mathrm{keV}$ photopeak of ${ }^{99 \mathrm{~m}} \mathrm{Tc}$.

In all patients, we performed planar imaging of the maxillary and mandibular areas in a $256 \times 256$ matrix, with $500 \mathrm{kcts}$ for every acquisition. During the acquisition, all patients maintained a comfortable jaw position.

After acquisition of the planar scans, a SPECT/CT emission transmission study was performed using a hybrid system (Infinia Hawkeye), a $360^{\circ}$ acquisition (high-resolution, low-energy collimators), a $128 \times 128$ matrix, a $3^{\circ}$ step, and $20 \mathrm{~s}$ per frame. Reconstruction was performed using both filtered backprojection and iterative ordered-subsets expectation maximization (10 subsets and 2 iterations), both with and without CT-based attenuation correction and a Hanning 3-dimensional postprocessing filter (cutoff frequency, 0.85 cycles $\cdot \mathrm{cm}^{-1}$ ). The CT portion of the study was acquired at $2.5 \mathrm{~mA}$ and $140 \mathrm{kV}$ over $220^{\circ}$, with a slice step of $1 \mathrm{~cm}$ and a slice time of $14 \mathrm{~s}$. Transmission data were reconstructed by filtered backprojection to produce cross-sectional attenuation maps in which each pixel represented the attenuation of the imaged tissue. Transmission and emission images were fused on a dedicated nuclear medicine workstation (Xeleris; GE Healthcare) using the Xeleris software package. The full field of view consisting of $20-40$ slices was completed in $10 \mathrm{~min}$. The radiation dose of the transmission data ranged from $1.3 \mathrm{mGy}$ at the center of the body volume to $5 \mathrm{mGy}$ at the surface.

Scintigrams (planar and SPECT/CT) were independently interpreted by a team of 2 experienced nuclear medicine physicians; CT, MRI, and orthopantomography images were interpreted by 2 experienced radiologists. CT, MRI, and SPECT/CT were reviewed without benefit of the clinical and radiologic information. Because the study was retrospective and explorative and assessed the available data from routine investigations, obtaining informed consent from the patients was not necessary.

\section{RESULTS}

Table 1 summarizes the clinical, histologic, and scintigraphic results of our patients. The final diagnosis was arrived at both clinically and histologically $(n=8)$ : 9 patients had mandibular osteonecrosis, 4 patients had maxillary involvement, and 2 patients had lesions affecting both the upper and the lower jaw.

\section{Bone Scan Findings}

Three-phase bone scintigraphy showed increased perfusion in 9 of 12 patients and an increased blood pool in 10 of 12 patients. In particular, the findings were abnormal in the mandibular area of 6 patients, and an increased flow was found in the maxillary area of 2 patients; in 1 patient, both the mandibular and the maxillary areas showed increased flow, compared with the contralateral region or the ipsilat- 
TABLE 1. Clinical Findings and Scintigraphic Results

\begin{tabular}{|c|c|c|c|c|c|c|c|c|}
\hline \multirow[b]{2}{*}{$\begin{array}{c}\text { Patient } \\
\text { no. }\end{array}$} & \multirow[b]{2}{*}{$\begin{array}{l}\text { Age } \\
\text { (y) }\end{array}$} & \multirow[b]{2}{*}{ Sex } & \multirow{2}{*}{$\begin{array}{c}\text { Reason for } \\
\text { taking } \\
\text { zoledronic acid }\end{array}$} & \multirow[b]{2}{*}{$\begin{array}{c}\text { Site of } \\
\text { necrosis }\end{array}$} & \multicolumn{2}{|c|}{ 3-phase flow imaging } & \multirow{2}{*}{$\begin{array}{c}\text { Site of focal } \\
\text { SPECT/CT } \\
\text { hyperactivity }\end{array}$} & \multirow[b]{2}{*}{ Final diagnosis } \\
\hline & & & & & Perfusion & $\begin{array}{l}\text { Blood } \\
\text { pool }\end{array}$ & & \\
\hline 1 & 54 & $\mathrm{~F}$ & $\begin{array}{c}\text { Bone metastases } \\
\text { secondary to } \\
\text { breast cancer }\end{array}$ & $\begin{array}{l}\text { Mandible } \\
\text { and maxilla }\end{array}$ & $\begin{array}{l}\text { Increased in } \\
\text { mandible }\end{array}$ & $\begin{array}{l}\text { Increased in } \\
\text { mandible }\end{array}$ & $\begin{array}{l}\text { Mandible and } \\
\text { mild in maxilla }\end{array}$ & $\begin{array}{l}\text { Necrosis in } \\
\text { mandible } \\
\text { and maxilla }\end{array}$ \\
\hline 2 & 74 & $\mathrm{~F}$ & $\begin{array}{c}\text { Bone metastases } \\
\text { secondary to } \\
\text { breast cancer }\end{array}$ & Mandible & $\begin{array}{l}\text { Increased in } \\
\text { mandible }\end{array}$ & $\begin{array}{l}\text { Increased in } \\
\text { mandible }\end{array}$ & Mandible & $\begin{array}{l}\text { Necrosis in } \\
\text { mandible }\end{array}$ \\
\hline 3 & 80 & M & $\begin{array}{l}\text { Bone metastases } \\
\text { secondary to } \\
\text { lung cancer }\end{array}$ & Maxilla & $\begin{array}{l}\text { Increased in } \\
\text { maxilla }\end{array}$ & $\begin{array}{l}\text { Increased } \\
\text { in maxilla }\end{array}$ & $\begin{array}{l}\text { Maxilla and } \\
\text { mild in mandible }\end{array}$ & $\begin{array}{l}\text { Necrosis in } \\
\text { maxilla } \\
\text { and afterward } \\
\text { also in mandible }\end{array}$ \\
\hline 4 & 60 & M & Multiple myeloma & $\begin{array}{l}\text { Mandible } \\
\text { and maxilla }\end{array}$ & $\begin{array}{l}\text { Increased in } \\
\text { maxilla and } \\
\text { mandible }\end{array}$ & $\begin{array}{l}\text { Increased in } \\
\text { maxilla and } \\
\text { mandible }\end{array}$ & $\begin{array}{l}\text { Maxilla and } \\
\text { mandible }\end{array}$ & $\begin{array}{l}\text { Necrosis in } \\
\text { mandible } \\
\text { and maxilla }\end{array}$ \\
\hline 5 & 74 & $\mathrm{~F}$ & Multiple myeloma & Mandible & $\begin{array}{l}\text { Increased in } \\
\text { mandible }\end{array}$ & $\begin{array}{l}\text { Increased in } \\
\text { mandible }\end{array}$ & Mandible & $\begin{array}{l}\text { Necrosis in } \\
\text { mandible }\end{array}$ \\
\hline 6 & 78 & $\mathrm{~F}$ & Multiple myeloma & Mandible & $\begin{array}{l}\text { Negative for } \\
\text { increase }\end{array}$ & $\begin{array}{l}\text { Negative for } \\
\text { increase }\end{array}$ & Mandible & $\begin{array}{r}\text { Necrosis in } \\
\text { mandible }\end{array}$ \\
\hline 7 & 72 & $\mathrm{~F}$ & $\begin{array}{c}\text { Bone metastases } \\
\text { secondary to } \\
\text { breast cancer }\end{array}$ & Mandible & $\begin{array}{l}\text { No flow imaging } \\
\text { executed }\end{array}$ & $\begin{array}{l}\text { No flow } \\
\text { imaging } \\
\text { executed }\end{array}$ & Mandible & $\begin{array}{l}\text { Necrosis in } \\
\text { mandible }\end{array}$ \\
\hline 8 & 74 & M & Multiple myeloma & Mandible & $\begin{array}{l}\text { Increased in } \\
\text { mandible }\end{array}$ & $\begin{array}{c}\text { Increased in } \\
\text { mandible }\end{array}$ & Mandible & $\begin{array}{r}\text { Necrosis in } \\
\text { mandible }\end{array}$ \\
\hline 9 & 86 & $\mathrm{~F}$ & $\begin{array}{c}\text { Bone metastases } \\
\text { secondary to } \\
\text { breast cancer }\end{array}$ & Mandible & $\begin{array}{l}\text { No flow imaging } \\
\text { executed }\end{array}$ & $\begin{array}{l}\text { No flow } \\
\text { imaging } \\
\text { executed }\end{array}$ & Mandible & $\begin{array}{l}\text { Necrosis in } \\
\text { mandible }\end{array}$ \\
\hline 10 & 65 & $\mathrm{~F}$ & $\begin{array}{c}\text { Bone metastases } \\
\text { secondary to } \\
\text { breast cancer }\end{array}$ & Mandible & $\begin{array}{l}\text { No flow imaging } \\
\text { executed }\end{array}$ & $\begin{array}{l}\text { No flow } \\
\text { imaging } \\
\text { executed }\end{array}$ & Mandible & $\begin{array}{l}\text { Necrosis in } \\
\text { mandible }\end{array}$ \\
\hline 11 & 74 & $\mathrm{~F}$ & $\begin{array}{c}\text { Bone metastases } \\
\text { secondary to } \\
\text { breast cancer }\end{array}$ & Mandible & $\begin{array}{l}\text { Negative for } \\
\text { increase }\end{array}$ & $\begin{array}{l}\text { Increased in } \\
\text { mandible }\end{array}$ & Mandible & $\begin{array}{r}\text { Necrosis in } \\
\text { mandible }\end{array}$ \\
\hline 12 & 74 & $\mathrm{~F}$ & $\begin{array}{c}\text { Bone metastases } \\
\text { secondary to } \\
\text { breast cancer }\end{array}$ & Mandible & $\begin{array}{l}\text { Increased in } \\
\text { mandible }\end{array}$ & $\begin{array}{c}\text { Increased in } \\
\text { mandible }\end{array}$ & Mandible & $\begin{array}{r}\text { Necrosis in } \\
\text { mandible }\end{array}$ \\
\hline 13 & 71 & $\mathrm{~F}$ & $\begin{array}{c}\text { Bone metastases } \\
\text { secondary to } \\
\text { breast cancer }\end{array}$ & Maxilla & $\begin{array}{l}\text { Increased in } \\
\text { mandible }\end{array}$ & $\begin{array}{l}\text { Increased in } \\
\text { mandible }\end{array}$ & $\begin{array}{l}\text { Mandible and } \\
\text { maxilla }\end{array}$ & $\begin{array}{l}\text { Necrosis in } \\
\text { maxilla and } \\
\text { afterward also } \\
\text { in mandible }\end{array}$ \\
\hline 14 & 61 & $\mathrm{~F}$ & $\begin{array}{c}\text { Bone metastases } \\
\text { secondary to } \\
\text { breast cancer }\end{array}$ & Maxilla & $\begin{array}{l}\text { Negative for } \\
\text { increase }\end{array}$ & $\begin{array}{l}\text { Negative for } \\
\text { increase }\end{array}$ & Maxilla & $\begin{array}{l}\text { Necrosis in } \\
\text { maxilla }\end{array}$ \\
\hline 15 & 64 & $\mathrm{~F}$ & $\begin{array}{l}\text { Bone metastases } \\
\text { secondary to } \\
\text { lung cancer }\end{array}$ & Maxilla & $\begin{array}{l}\text { Increased in } \\
\text { maxilla }\end{array}$ & $\begin{array}{l}\text { Increased in } \\
\text { maxilla }\end{array}$ & Maxilla & $\begin{array}{l}\text { Necrosis in } \\
\text { maxilla }\end{array}$ \\
\hline
\end{tabular}

eral adjacent bone segment, as confirmed by the timeactivity curve. In 1 patient, 3-phase bone scintigraphy revealed normal perfusion with an increased blood pool in the mandible, whereas in 2 patients the perfusion and blood-pool phases showed no particular changes.

At the metabolic phase, SPECT findings were considered positive in all patients and showed abnormal focal hyperactivity in the maxillary area of 2 patients, in the mandibular area of 9 patients, and in both the maxillary and the mandibular areas of 4 patients. Two patients showed severe focal tracer uptake in the maxilla and an additional mild focus in the mandible. These findings were more clearly visualized on SPECT/CT and were due to initial osteonecrosis as demonstrated by clinical follow-up (Fig. 1). In another patient (patient 15; Table 1), SPECT highlighted involvement of the zygomatic and ethmoid bones-involvement that had not been seen at the clinical assessment. Wholebody scintigraphy showed remote and multiple metastases in all patients.

\section{SPECT/CT Clinical Contribution}

Fusion SPECT/CT highlighted the metabolic difference between necrosis and areas of reactive osteoblastic hyperactivity, compared with normal bone. SPECT/CT had particular 


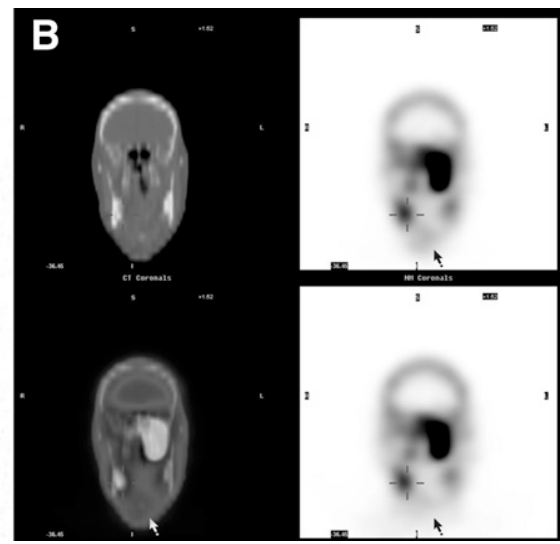

FIGURE 1. A 79-y-old man, with lung cancer and bone metastases, treated with zoledronic acid. (A) Planar images showed gross area of tracer uptake in left maxilla, due to osteonecrosis, and mild focus in right mandible (arrow). (B) Hybrid SPECT/CT more precisely defined extension of osteonecrosis in left maxilla and better demonstrated focus in right mandible (triangulation). Focus was then confirmed as initial osteonecrosis by follow-up.

value in 8 patients by allowing more precise localization of a core of osteonecrosis surrounded by increased bone uptake, reflecting decreased metabolism in the necrotic focus and the reaction of the viable bone (Figs. 2 and 3). Hybrid imaging showed in 7 patients focally increased uptake in areas of CT cortical resorption. Moreover, SPECT/CT discriminated involvement of the soft tissue from bone. In all patients, bone SPECT/CT findings correlated with clinical findings for position and severity of lesions.

\section{Orthopantomography Findings}

Orthopantomography showed, in 15 patients, bone destruction and osteolytic areas corresponding to areas of clinical involvement; however, orthopantomography was unable to accurately differentiate necrotic bone from normal bone, and subperiosteal new-bone formation was not usually evident.

\section{$\mathrm{CT}$ and MRI Findings}

CT and MRI showed anomalies in all symptomatic patients: in 4 patients, CT showed cortical resorption and interruption and clear areas of both osteolysis and osteosclerosis. MRI was able to detect soft-tissue involvement. In particular, MRI showed thickening soft tissue and hyperemia in 3 patients; in patients with marked swelling, edema of soft tissue was detectable on turbo short- $\tau$ inversion recovery images as a high signal intensity. All patients showed involvement of cancellous bone presenting as a low signal intensity on T1-weighted images and a mild hyperintensity on T2-weighted and turbo short- $\tau$ inversion recovery images. MRI was not able to demonstrate cortical bone destruction.

\section{Histologic and Clinical Findings}

In 14 patients with exposed bone ( 8 patients at the moment of nuclear medicine investigation), histologic examination confirmed inflammatory necrosis showing a loss of osteocytes from their lacunae and peripheral resorption. Moreover, formation of granulation tissue and preservation of capillary microcirculation were observed.

In 2 patients, swabs showed bacterial flora commonly present in the oral cavity; in the remaining 13 patients, cultures revealed several pathogenic microorganisms: $\mathrm{Bac}$ teroides, Enterobacteriaceae, and Streptococcus group F.

In all patients, treatment included antibiotic therapy, which was useful for achieving complete remission of symptoms; all symptomatic patients underwent hyperbaric oxygen therapy, but such therapy proved useless for improving the clinical aspects of the lesions. The exposed bone was covered with a mucosal flap in 6 patients, but in 3

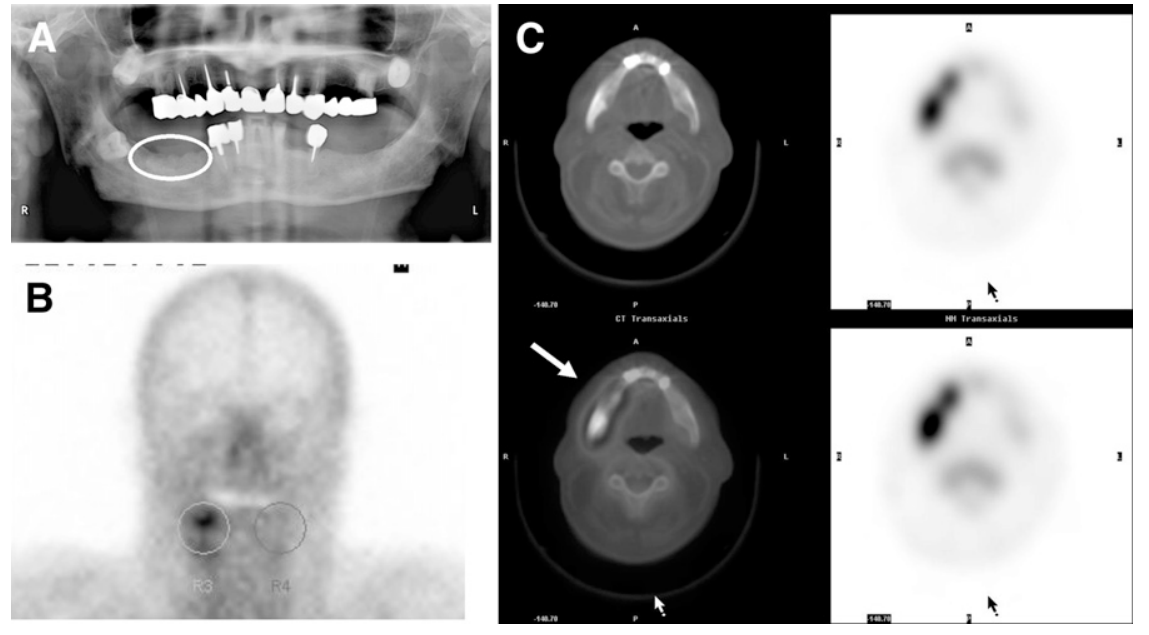

FIGURE 2. A 73-y-old woman, affected by multiple myeloma, previously treated with bisphosphonates. (A) Orthopantomography showed area of bone cortical irregularity (circled) in right mandible. (B) Threephase bone scanning revealed increased blood pool (circled). (C) Hybrid SPECT/CT allowed definition of area of osteonecrosis (arrow) with neighboring hyperactive viable bone. 
FIGURE 3. A 63-y-old woman with breast cancer and bone metastases treated with zoledronic acid for $2 \mathrm{y}$. (A) Orthopantomography showed area of cortical disruption (circled) in right mandible. (B) Three-phase bone scanning revealed increased blood pool (circled). (C) Hybrid SPECT/CT well demonstrated a necrotic core (arrow) and neighboring viable bone.
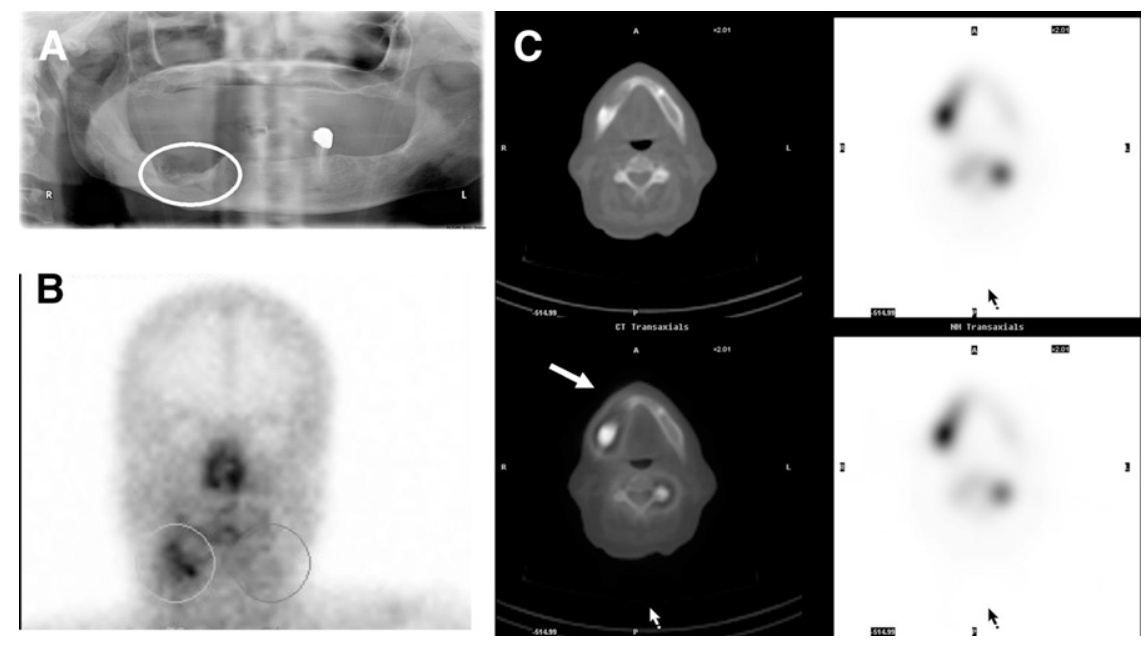

of these patients, a fistula developed after 3 mo, with formation of abscesses for cutaneous drainage. In these patients, surgically invasive treatment was used.

\section{DISCUSSION}

Marx and Stern in 2003 (8) first described avascular bone necrosis associated with the use of pamidronate in myeloma patients. Several other cases of osteonecrosis of the jaw after therapy with bisphosphonates were subsequently reported (1-3). The recently published results (9) of a prospective analysis of 252 patients with neoplasia showed osteonecrosis of the jaw at a frequency of about $6.7 \%$ after bisphosphonate treatment.

The role of bisphosphonates in the etiology and pathogenesis of osteonecrosis of the jaw remains obscure; both surgical dental procedures and a reduction of blood supply resulting from local trauma may be involved. An association between bisphosphonates and dental trauma, although strong, cannot with certainty be considered the predisposing cause of osteonecrosis of the jaw. Osteonecrosis of the jaw associated with bisphosphonates may be present subclinically; dental disease or, alternatively, dental extraction or dental trauma may reveal underlying osteonecrosis (10).

Radiologic investigations are the first routine tools. Conventional orthopantomography provides an excellent general assessment of the entire jaw, but mineral loss must be as high as $30 \%-50 \%$ to be visible. In our patients, orthopantomography showed bone destruction but was not able to differentiate necrotic from normal bone or osteolytic lesions from metastases.

Radiotracer accumulation on scintigraphy can show pathophysiologic changes in bone earlier than conventional radiography. Bone scanning is commonly and routinely used in oncology and nononcology patients. Three-phase bone scintigraphy allows the assessment of associated inflammation or infection with high sensitivity.

In the past, nuclear medicine physicians increased the diagnostic accuracy of bone scintigraphy by integrating planar imaging with SPECT, thus improving lesion detection and localization (11). In particular, Savelli et al. (6) compared SPECT with bone planar acquisitions in patients with bone metastases and found greater diagnostic accuracy for SPECT, particularly for evaluating patients with a single skeletal metastasis.

In the last decade, hybrid systems producing a direct fusion of SPECT and CT studies have been introduced. Transmission and emission data are acquired during the same session without moving the patient, thus allowing the correct registration of the 2 datasets. Several published papers have demonstrated the value of SPECT/CT in oncology patients during nuclear medicine investigations $(7,12)$.

Few reports have proposed the use of integrated SPECT/ CT for bone scanning. Horger et al. (13) used a hybrid camera combining SPECT and CT for the classification of skeletal lesions and obtained a significantly higher specificity for SPECT/CT than for SPECT alone. Romer et al. (14), using SPECT and dual-slice reduced-dose (130 keV, $40 \mathrm{~mA} \cdot \mathrm{s}$ ) spiral CT, clarified in 44 oncology patients more than $90 \%$ of those findings classified as indeterminate on SPECT and planar imaging. Utsunomiya et al. (15) and Even-Sapir (16) also showed hybrid SPECT/CT to increase the accuracy of bone scanning.

To our knowledge, this is the first report concerning bone scintigraphy and SPECT/CT for evaluation of osteonecrosis of the jaw in association with bisphosphonate treatment.

Our study confirmed the high sensitivity of bone scanning, especially in the early stages of disease. Inflammation was associated with osteonecrosis of the jaw. In fact, increased perfusion was detected in 9 of 12 patients and an increased blood pool in 10 of 12 . In our patients, the longer the treatment with bisphosphonates was, the greater was the inflammation, and this correlation extended to symptom severity and the extent of jaw bone lesions.

Bone scanning had a positive predictive value in 2 patients (patients 3 and 13; Table 1). These 2 patients clearly showed focal osteonecrosis of the jaw in the 
maxillary region and an initial new focus in the mandible. In these patients, the areas of mild hyperactivity were not clearly demonstrated in mandibular bone on planar scanning and were better visualized on hybrid SPECT/CT. In another patient (patient 15; Table 1), SPECT/CT highlighted and localized involvement of the zygomatic and ethmoid bones, more precisely defining the extent of disease.

The results of our SPECT/CT investigations were integrated with the results of diagnostic high-resolution CT. Hybrid imaging increased the ability to identify the margin between an osteonecrotic core and neighboring viable bone. Surgical approaches may not be entirely successful in removing necrotic bone because of the difficulty of distinguishing between viable and necrotic bone. In such cases, hybrid SPECT/CT was useful because it helped surgeons to remove only necrosis, with significant sparing of viable bone.

The additional radiation burden due to the CT component of hybrid SPECT/CT is on the order of $0.5 \mathrm{mSv}$. This dosimetric value is considerably smaller than the dose delivered to the patient by a typical diagnostic CT scan.

Of course, with hybrid SPECT/CT the lack of specificity in bone scanning remains a serious challenge, because every type of dental disease can produce focal tracer uptake and mimic osteonecrosis of the jaw. In our study, patients were carefully evaluated to exclude other dental diseases. Moreover, osteonecrosis of the jaw was definitively diagnosed in the maxillary or mandibular areas of edentia.

In patients who are not clinically selected, the rate of false-positive scan findings would be too high $(17,18)$. Thus, bone scanning with hybrid SPECT/CT cannot be proposed as a screening procedure to detect osteonecrosis of the jaw in all oncology patients treated with bisphosphonates. Only after an accurate clinical examination excluding dental disease and supporting the suspicion of osteonecrosis of the jaw can bone scanning by hybrid SPECT/CT represent a useful imaging tool to disclose the focus of necrosis, precisely defining the extent of disease.

\section{CONCLUSION}

Our results indicate that bone scanning can be a useful technique to diagnose osteonecrosis of the jaw in appropriately selected oncology patients who are taking bisphosphonates. Moreover, hybrid SPECT/CT can increase the accuracy of conventional bone scintigraphy, providing a precise functional-anatomic correlation and better defining the relationship between necrosis and neighboring viable bone. Further studies on larger series are needed to define the clinical impact of hybrid technology on surgical treatment of osteonecrosis of the jaw.

\section{REFERENCES}

1. Marx RE, Sawatari Y, Fortin M, Broumand V. Bisphosphonate-induced exposed bone (osteonecrosis/osteopetrosis) of the jaws: risk factors, recognition, prevention, and treatment. J Oral Maxillofac Surg. 2005;63:1567-1575.

2. Bagan JV, Murillo J, Jimenez Y, et al. Avascular jaw osteonecrosis in association with cancer chemotherapy: series of 10 cases. J Oral Pathol Med. 2005;34:120-123.

3. Carter G, Goss AN, Doecke C. Bisphosphonates and avascular necrosis of the jaw: a possible association. Med J Aust. 2005;182:413-415.

4. Woo SB, Hellstein JW, Kalmar JR. Narrative review: bisphosphonates and osteonecrosis of the jaws. Ann Intern Med. 2006;144:753-761.

5. Ruggiero S, Gralow J, Marx RE, et al. Practical guidelines for the prevention, diagnosis, and treatment of osteonecrosis of the jaw in patients with cancer. J Oncol Pract. 2006;2:7-14.

6. Savelli G, Maffioli L, Maccauro M, De Deckere E, Bombardieri E. Bone scintigraphy and the added value of SPECT (single photon emission tomography) in detecting skeletal lesions. Q J Nucl Med. 2001;45:27-37.

7. Keidar Z, Israel O, Krausz Y. SPECT/CT in tumor imaging: technical aspects and clinical applications. Semin Nucl Med. 2003;33:205-218.

8. Marx RE, Stern D. Oral and Maxillo-Facial Pathology: A Rationale for Diagnosis and Treatment. Carol Stream, IL: Quintessence; 2003:36-8.

9. Bamias A, Kastritis E, Bamia C, et al. Osteonecrosis of the jaw in cancer after treatment with bisphosphonates: incidence and risk factors. J Clin Oncol. 2005;23:8580-8587.

10. Dunstan C, Felsenberg D, Seibel MJ. Therapy insight: the risk and benefits of bisphosphonates for the treatment of tumor-induced bone disease. Nat Clin Pract Oncol. 2007;4:42-55.

11. Israel O, Jerushalmi J, Frenkel A, et al. Normal and abnormal single photon emission computed tomography of the skull: comparison with planar scintigraphy. J Nucl Med. 1988;29:1341-1346.

12. Schillaci O, Danieli R, Manni C, Simonetti G. Is SPECT/CT with a hybrid camera useful to improve scintigraphic imaging interpretation? $\mathrm{Nucl} \mathrm{Med}$ Commun. 2004;25:705-710.

13. Horger M, Eschmann SM, Pfannenberg C, et al. Evaluation of combined transmission and emission tomography for classification of skeletal lesions. AJR. 2004; 183:655-661.

14. Romer W, Nomayr A, Uder M, Bautz W, Kuwert T. SPECT-guided CT for evaluating foci of increased bone metabolism classified as indeterminate on SPECT in cancer patients. J Nucl Med. 2006;47:1102-1106.

15. Utsunomiya D, Shiraishi S, Imuta M, et al. Added value of SPECT/CT fusion in assessing suspected bone metastasis: comparison with scintigraphy alone and nonfused scintigraphy and CT. Radiology. 2006;238:264-271.

16. Even-Sapir E. SPECT/multislice low-dose CT: a clinically relevant constituent in the imaging algorithm of nononcologic patients referred for bone scintigraphy. J Nucl Med. 2007;48:319-324.

17. Tow DE, Garcia DA, Jansons D, Sullivan TM, Niederman R. Bone scan in dental diseases. J Nucl Med. 1978;19:845-847.

18. Ahuja RB, Scoutar DS, Moule B, Bessent RG, Gray H. Comparative study of technetium- $99 \mathrm{~m}$ bone scans and orthopantomography in determining mandible invasion in intraoral squamous cell carcinoma. Head Neck. 1990;12: 237-243. 